\title{
Literature Female Travel: The Vision of Spain Throughout Six Foreign Writers ${ }^{8}$
}

\author{
Lorena Barco Cebrian \\ Assitant Professor in Paleography, University of Malaga, Spain
}

doi: 10.19044/esj.2016.v12n32p54 URL:http://dx.doi.org/10.19044/esj.2016.v12n32p54

\begin{abstract}
Travel literature is a genre very known by the historiography; the researchers have been analyzed from the journeys of the Antiquity up to the Contemporaneousness. Nevertheless, those studies have showed a special interest for the travel literature produced by masculine subjects, whereas the literature produced by female writers has not been treated up to very recent dates. For it, in this work we propose to announce a series of women writers, some of them very known already, but others practically unknown in our country. These women, intrepid and bold travelers, travelled to Spain throughout the centuries of the Modernity, extending the period chronological until the Nineteenth century. It is of six women writers whose literary production, in most cases, has not been translated into Spanish.
\end{abstract}

Keywords: Travel literature, female travelers-writers, SeventeenthNineteenth centuries, Madame Genlis, Countess d'Aulnoy, Mrs. Jemima Kindersley, Sophia Barnard, Lady Chatterton, Ann Lady Fanshawe

I will use every reasonable criticisms and never respond to satires. I will continue with calm, perseverance and firmness the work begun. Injustice and calumny cannot shoot me down or lose heart. I will try even transforming then useful. I want to serve me to form, to strengthen my character, to give me that patience that protects the humor, this elevation makes disdaining revenge, and that record that eventually triumph over all (Genlis, 2010, p. 42).

\footnotetext{
${ }^{8}$ This work has been done thanks to the scholarship program Chawton House Library of the University of Southampton which was granted me in 2014. Chawton House Library is a foundation belonging to the University of Southampton that focuses on women's literature in a first moment of the Romantic era, but gradually has been making an opening to the literary production and female scientist of all time, focusing primarily on the centuries of modernity. To learn more about this institution and scholarships offered therein can consult the following website: http://www.chawtonhouse.org/
} 


\section{Introduction}

This study aims to publicize the name of six foreign, English and French writers, who wrote about Spain at some point in her literary career. Most of them tell their trips to the Iberian Peninsula or the Canary Islands between the seventeenth and nineteenth centuries. Therefore, we demonstrate a development in the perception of Spain, the Other (Almarcegui, 2011, pp. 283-290) along virtually the entire modern age, even reaching moments of contemporaneity. Hence, it wants to offer the spatial vision of urban and rural areas, although more present, the first, that these females gave over Spain in their different literary productions.

There are six writers, of which some of them have been treated extensively in the literature, either historiographical, literary or philological. However, others have gone unnoticed by the scientific literature. In fact, there is virtually no bibliographic references to them, so the challenge has been to locate them. In addition, most of these females are unknown in our country, to which should be added the virtual absence of translations of her texts to Spanish (Marchant Rivera, 2004, pp. 224-232; FernándezMontesinos, 2004, pp. 224-232).

The study has been focused on locating the works concerning these six foreign writers who refer to our country. From there, we tried to reconstruct part of their biographies, in order to better understand their works. At the same time, it aims to see and appreciate the vision of Spain had these females, very different from their peers, and travelers, male.

These writers are: Stéphanie Félicité Genlis Bruslart, Madame Genlis; Henrietta Maria Georgiana Chatterton, Lady Chatterton; Ann Lady Fanshawe; Sophia Barnard; Marie-Catherine La Mothe Aulnoy, Countess d'Aulnoy; and Mrs. Jemima Kindersley. Six women who lived in different eras, whose origins are also disparate experiences of dissimilar lives, but nevertheless were attracted by reasons, perhaps like to travel or learn more about a neighboring country in some cases, but distant as to customs, hence the exotic of Spain in the eyes of these writers.

\section{Reflections on the literature of travel through History}

Indeed, this literary genre, long considered as a minor genre, has always existed; from the earliest times, man has seen the need to travel for various reasons and the need to record in writing of those incidents. Therefore, we have a vital documentary source for history, which is played us from antiquity (Gómez Espelosín, 2006, pp. 59-75) to the contemporary view that the traveler has had, depending on the time, visiting the territory.

Increasing the literature, specially travel, has been exponentially improved in recent decades, which does nothing but give a good account of the rise of this literary side not only in literary and philological studies, but 
also in the historiographical studies ${ }^{9}$. Moreover, more specifically, in recent years it has seen both qualitative and quantitative developments regarding the analysis of travel literature produced by adventurous women ${ }^{10}$.

${ }^{9}$ Some of the books and articles on travel literature that have seen the light in recent decades, which we have used here have been: SERRANO, M. M.: Viajes de papel: repertorio bibliográfico de guías y libros de viaje por España 1800-1902, Barcelona, Publicaciones de la Universidad de Barcelona, 1993. GARCíA MERCADAL, J.: Viajes extranjeros por España y Portugal desde los tiempos más remotos hasta comienzos del siglo XX, Valladolid, Junta de Castilla y León, 1999, 6 vols. Krauel Heredia, B.: Viajeros británicos en Andalucía de Christopher Hervey a Richard Ford (1760-1845), Málaga, Publicaciones de la Universidad, 1986. GARCíA-Romeral PÉREZ, C.: Bio-bibliografía de viajeros por España y Portugal (siglo XIX), Madrid, Ollero y Ramos, 1999. FERnÁndeZ-MonTESINOS, A. E.: (coord.), Viajeras románticas en Andalucía. Antología, Sevilla, Centro de estudios andaluces. Consejería de la Presidencia, 2008. MAJAdA NEILA, J.: 500 libros de viaje sobre Málaga, Benalmádena, Caligrama ediciones, 2001. ROMERO TOBAR, L.: "Imágenes poéticas en textos de viajes románticos al Sur de España”, Revista de literatura, Tomo 73, 145 (2011), pp. 233-244. TAMARIT VALLÉS, I.: Representaciones de la mujer española en el imaginario francés del siglo XVIII, Tesis doctoral, Universidad de Valencia, 2004. MitcheLL, D.: Viajeros por España. De Borrow a Hemingway, Madrid, Mondadori, 1989. FreIRE LóPEZ, A.M.: "España y la literatura de viajes en el siglo XIX", en Anales de literatura española, 24 (2012), pp. 67-82. ARRAnZ LAGO, D. F.: "La literatura de viajes en el tiempo: orígenes e hitos”, en Crítica, 990 (2014), pp. 76-79. AlburQUERQUE GarCíA, L.: "Literatura de viajes y siglo XVIII español: repaso y sistematización”, Miríada hispánica, 9 (2014), pp. 37-51. SALIDO LÓPEZ, P.V.: "La literatura de viajes como fuente para la investigación", en Collado Yurrita, M. A. Y HeRnández Adrover, J. J. (coords.), I Jornadas Doctorales de Castilla-La Mancha: El doctorado: impacto social y futuro profesional, Ciudad Real, 2011, p. 70. HENRíQUEZ JiMÉNEZ, S. J.: "La lectura de la literatura de viajes: nuevos textos, líneas de investigación, elementos y fundamentos teóricos”, en MARRERO HENRíQUEZ, J. M. (coord.), La luz no interrumpida, 2012, pp. 293-304. AlMARCEgui ElduAYen, P.: "El otro y su desplazamiento en la última literatura de viaje”, en Revista de literatura, Tomo 73, 145 (2011), pp. 283-290. BAS MARTín, N.: "El viaje como formación: ejemplos de la literatura europea del siglo XVIII”, en Historia de la educación: Revista interuniversitaria, 30, 2011, pp. 129-143. PeÑATE RIVERO, J.: "Viajeros españoles por Europa en los años cuarenta del siglo XIX: tres formas de entender el relato de viaje”, Revista de literatura, Tomo 73, 145 (2011), pp. 245-268. ChAVEs MARTín, M. A.: "El viaje y sus relatos. Una aproximación a la construcción de la imagen de la ciudad histórica”, Icono14, Vol. 10, 2 (2012), pp. 57-83. ORTEGA RomÁn, J. J.: "La descripción en el relato de viajes: los tópicos", Revista de filología románica, Extra 4 (2006), pp. 207-232. BAS MARTín, N.: "Los repertorios de libros de viajes como fuente documental”, Anales de documentación: Revista de biblioteconomía y documentación, 10 (2007), pp. 9-16. MARTínEz AlONSO, P. J.: Libros de viajes alemanes e ingleses a España en el siglo XX, Tesis doctoral, Universidad Complutense de Madrid, 2003.

${ }^{10}$ Marchant RiverA, A.: "Escritura femenina y viajera II: Dora Quillinam, Margaret Thomas y Valéire de Gasparin en el Cementerio Inglés de Málaga”, en GÓMEZ YEBRA, A. (coord.), Patrimonio literario andaluz (IV), 2011, pp. 69-84; MARCHANT RiverA, A.: "El cementerio inglés de Málaga y sus fuentes historiográficas: los libros de viaje femeninos del siglo XIX”, en MARCHANT RIVERA A. Y RodRíGUEZ MARÍn, F. (coords.), La muerte desde la arqueología, la historia y el arte, 2013, pp. 75-92; MARCHANT RIVERA, A. Y MUÑOz JiMÉnEZ, A. B.: "Escritura francófila y anónima Matilda Betham Edwards y Caroline H. 
Travel literature has been and remains a heterogeneous literary genre, that it to say every traveler-writer had his or her own guidelines and its own perception of the Other, which was reflected unevenly in different stories (Tamarit Vallés, 2004, p. 42). However, sometimes, the traveler story has been characterized by approaching the memories, the epistolary genre, or the geographical description without further also. This fact is no stranger to women who dedicated themselves to this kind of literary genre. Thus, we find stories in epistolary form, with memories, with more geographic descriptions, etc. However, it should be noted that within this genus has also been an isolation of women within it. Something that is no stranger to other literature, especially historical. That is, although there were many good traveling-writers throughout the centuries discussed here, the truth is that most of them are still unknown today, or many others have been forgotten (Montoro Fernández, 2014, p. 43). While on the other hand, travelers-writers have been studied, translated and included in the curricula for historical example, more comprehensively. Hence, the texts of Washington Irving, Richard Ford, Joseph Townsend and many others are based on historical studies, while the stories of their colleagues females are not (Fernández Montesinos, 2004, p. 224 and Gijón Jiménez, 2014, pp. 339-354).

These authors used to write her adventures, trips and stories from foreign lands, but not many of them published their productions. In fact, most published them under pseudonyms, or remained unpublished until the eighteenth and nineteenth centuries (Fernández Montesinos, 2004, p. 224) occurred, especially in England and France, with an increase in the consumption of this type of literature, which led many printers collect previous works hitherto unknown authors. Indeed, very few females

Pemberton en el cementerio inglés de Málaga (1867)”, en Gómez YeBrA, A. (coord.): Estudios sobre el patrimonio literario andaluz IV, 2012, pp. 81-96. MONTORO FERNÁNDEZ, F.: "Mujeres viajeras y Vélez-Málaga”, Sociedad: boletín de la Sociedad de Amigos de la Cultura de Vélez-Málaga, 13 (2014), pp. 43-48. Simón Alegre, A. I. y SANZ ÁlvAREZ, A.: "Prácticas y teorías de descubrir paisajes: viajeras y cultivadoras del estudio de la geografía en España, desde finales del siglo XIX hasta el primer tercio del XX", Arenal: Revista de historia de las mujeres, Vol. 17, 1 (2010), pp. 55-79. SuÁrEZ SuÁREZ, C.: "Viajeras y aventureras (I)", en CID LÓPEZ, R. M. (coord.), Horas de radio: sobre mujeres e historia, 2013, pp. 82-86. SuÁREZ SuÁREZ, C.: "Viajeras y aventureras (II)”, en CID LóPEZ, R. M. (coord.), Horas de radio: sobre mujeres e historia, 2013, pp. 87-90. OZLEM, E.: “A challenge to travel Literature and stereotypes by two turkish women: Zeyneb Hanoum and Selma Ekrem”, Feminismo/s, 4 (2004), pp. 61-67. MidDlETON, D.: Victorian Lady Travellers, Chicago, Academy, 1982. FERRús ANTÓN, B.: "Emilia Serrano, baronesa de Wilson, y la literature de viajes: "Maravillas americanas” y "América y sus mujeres", Cuadernos de Ilustración y Romanticismo: Revista Digital del Grupo de Estudios del siglo XVIII, 17 (2011), pp. 1-10. MARCILlAS PIQUER, I.: "Literatura de viajes en clave femenina: los pre-textos de Aurora Bertrana y otras viajeras europeas”, Revista de filología románica, 29-2 (2012), pp. 215-231. 
published under her real name, because society subjected them to a profound criticism and compared with their male counterparts. Thus female literary output was criticized as less valuable than men, as it was assumed that it was made from a more personal and subjective perspective, whose works were imbued with likes and loves, passions and heartbreaks, with a certain halo of paroxysm, that had little to do with what described by their male colleagues of profession. They preferred to focus more on their own sex and often ignored the Spanish females, for example, in the stories of trip to Spain. In addition, when they approached the Spanish woman it was always surrounded by exoticism or was described through a prism that seeped the reality. While traveling females in their stories, however, were closer to the reality of women in this Spanish case, and fixed more on the customs of the daily life of those women, who in many cases had little to do with the traveling treading our country. This is not surprising since the literature, like many other areas of life, has a sexual component, that is to say, there is a clear distinction between male and female literature (Mékouar-Hertberg, 2014, p. 14; Marcillas Piquer, pp. 215-231).

In fact, the stories of these women writers usually talk about female subjects of their own social position. That is, women who wrote about Spain because they were here, either because they were interested for their professional work were women who belonged to high society. This meant that when they came to our country also interacted with females of their same social position. This allows us to reconstruct, under the orbit of the Other, the life led by these highborn women in our country. However, women of rural areas are not reflected in these stories, and when they do refer to it in passing and obliquely.

The goal of most of these women was not merely the literary production for the reader, but many of them saw in this production scriptural safe passage. Indeed, most women in the period treated here did not have many distractions in their daily lives; thus, most devoted to household chores of child rearing and maintenance of the dwelling. Therefore, they found in writing a way of salvation, a way of liberation from bondage in everyday regarding domestic tasks to be performed. It was therefore an evasion of the tasks imposed by society to these females, since we are talking about a predominantly patriarchal society where women did not have many areas where socializing (Tamarit Vallés, 2004, pp. 155-173). Therefore, the writing became a way of claim and exit to the outside, socialize differently as established by the society (Fernández-Montsinos, 2004, p. 225).

Throughout the following pages, we propose to approach each of the six women who locate in Chawton House Library writing about Spain. Approaching her biography, and her literary career and her stories of Spain. We have agreed to present them in chronological criterion, in order to 
examine more comfortably evolution over several centuries of this female travel literature.

\section{Spain in the travel Francophone and Anglophone literary}

Of the six writers analyzed here, three of them have been treated by historiography, literature and philology. We refer to Madame Genlis, the Countess d'Aulnoy and Lady Chatterton. Where the first two are the most famous, as her literary output was much more prolific than the rest of her classmates. Therefore, the existing literature on them is also higher, editions of her writings are numerous, although, however, still suffer from not being fully translated into Spanish. With all that, this would bring to our literature to expanding the vision of these females on multiple issues. The third one, Lady Chatterton, is also known, though perhaps more in France and England than in Spain, but in the same way, there are several studies that have seen the light and discuss her and her literary production.

On the other hand, the other three writers to which we refer here are much unknown, especially in our country. However, in Spain they are almost anonymous and unknown not only in the literary or philological world, but also historical. These are Mrs. Jemima Kindersley and Lady Ann Fanshawe; while the other remaining writer, Sophia Barnard, is virtually absent in all literature, so rebuilding her life is very complicated. Therefore here we only intend to make is known here and in a future work to deepen both her biography and her works.

\section{Lady Ann Fanshawe (1625-1680) ${ }^{11}$}

This is one of the least known English authors in Spain; her literary production is not as large as most of her mates here analyzed. However, outside our country it has more knowledge about her, although it is still very scarce in the international scene (Torralbo Caballero, 2010, pp. 85-99; Loftis, 1979; Basnett; Davison, 2004). The work we have used are her Memoirs, Lady Ann Fanshawe it introduces us to her life, making a family tree of the whole family to get to her. Similarly explains the adventures lived along the trips with her husband, Sir Richard Fanshawe, and precisely in one of those trips landed in Spain, where she toured almost the entire country, from Bilbao to Malaga, visiting various places she describes in her work.

Lady Fanshawe struggled throughout her life together her husband and, as we must not forget, she had to live the whole process of political

\footnotetext{
${ }^{11}$ Here we only intend to approach the life and work of this woman, as we are working more profusely in her work, whose results we hope will come to light in an article dedicated exclusively to her person in the near future.
} 
instability led by Cromwell. In all this turmoil, Sir Richard Fanshawe ${ }^{12}$ was arrested and suffered different punishments. Therefore, to free her husband and gain political favor, Lady Fanshawe even when she was in need of impersonating the man to be taken into consideration, and was known as Lord Clarendon (Fanshawe, 1774, pp. 13-15). They had several children over those years. Specifically, six sons and eight daughters. The first were: Harrison, who was born on February 22, 1645 in Oxford, died that same year. Henry, who was born in London on July 30, 1647 and died on October 20, 1650, whose remains were buried in Paris. Richard, who was born on June 8, 1648 and died before October 1650. His fourth son was also named Henry, who was born in November 1657, and died that same year. Richard was next, which was released on June 26, 1663 in Lisbon, but only survived for a few hours. Finally, her sixth son, who was also named Richard, was born in Madrid on August 6, 1665, and was the only man who survived his parents (Fanshawe, 1774, p. 28).

Daughters were: Anne, who was born on June 7, 1646 in Jersey, but died on July 20, 1654 in Tankersley, Yorkshire. The second was Elizabeth, who was born in Madrid on July 13, 1649, but died a few days, burrowing into the French Hospital of the Spanish capital. A third will also put Elizabeth, this was born the day of San Juan of 1650, however, and despite her parents, also died at six years. Katherine was next, was born on July 30, 1652, happily survived their parents, never married and died in 1705. The fifth girl was Margaret, was also born in Tankersley, Yorkshire, on October 8, 1653, also she survived their parents and married Vincent Grantham. The sixth daughter was Ann, who was born in Kent on 22 February 1655. Mary was next, who was born on July 12, 1656 in London, but died in August 1660 in Hertford. Finally, the eighth daughter was Elizabeth, who was born on February 22, 1662, but nevertheless, we lose track after the year 1679 (Fanshawe, 1774, pp. 29-30).

They traveled several times to Spain, some of their aim was to Madrid, others, however, was Cadiz. So we know that, for example, February 23, 1664 landed in the Cadiz (Fanshawe, p. 16). Later, they settled in Madrid, and from there Sir Richard had to travel to other places like Lisbon. Finally, Sir Richard died in Madrid and his body would be moved to England where he was buried. Lady Fanshawe died on 20 January 1680 at the age of fifty-five years, only four years before she wrote the work that we are dealing here, her Memoirs (Fanshawe, 1774, pp. 20-26).

"The next morning, stilo novo, came in a Levant wind, which blew the fleet so forbibly, that we could not possibly land until Monday,

\footnotetext{
${ }^{12}$ He was born in Ware Park in 1608, in 1630 he became ambassador in the Spanish Court, hence the journey that made the marriage throughout the country (Fanshawe, pp. 2-3).
} 
the $7^{\text {th }}$ of March, at 10 o'clock in the morning. They came the Governor, Don Diego de Ibara, aboard, accompanied by most of the persons of quality of that town, with many boats for the conveyance of our family, and a very rich barge, coverd with crimson damask fringed with gold, and Persia carpets under foot" (Fanshawe, 1774, p. 166).

"On Thursday the $3^{\text {rd }}$ of April, 1664, we took our leave of the assistant and the rest of that noble company at Seville. The Conde Molina, who was Asistente of Seville, presented me with a young lion; but I desired his Excellency's pardon that I did not accept of it, saying I was of so cowardly a nature, I durst not keep company with it. In the same manner as they received us, so they accompanied us a league onward on our way, whereupon my husband alighting out of the Conde's coach, and having with me taken leave of all the company, both he and I got upon horseback; and here we took our leave of my Lord Dongan, wo with great kindness brought us so far from Xerez. Some of the Malaga merchants of Seville accompanied us on our journey. That night we lay at Carmona; and on the $4^{\text {th }}$ of April at Fuentes, the Onor of the Marquis, who is now at Paris, Ambassador from the King of Sapin to that Court. On the $5^{\text {th }}$ we lay at Ezija, where we received noble entertainment from the noblemen and gentlemen of that town; where we stayed till Thrusday, the 8 th April, and after paying thanks to those persons that had so well ordered that noble entertainment with great civility to us, we went that night to Cordova, where, a league before we came to the town, we were met by the Corregidor (Fanshawe, 1774, pp. 181-183).

\section{Marie-Catherine La Mothe Aulnoy, Countess of d'Aulnoy (1650-1705)}

This is a French author on which there have been numerous works (Gunther, 2010, pp. 127-136; Triquet, 2007, pp. 34-49; Hardy, 1982, p. 40; Harlin Mcburney, 1960, pp. 12-19; Campa Carmona, 2003, pp. 161-174; Pamer, 1975, pp. 237-253), born about 1650 near Barneville. In 1666 she married François de la Motte, who became Baron d'Aulnoy in 1654. However, even though she called herself countess, the truth is that never got the title. Her mother led and instigated a persecution against her husband, so the Countess d'Aulnoy had to flee and took refuge in Spain, thanks to the contacts of her mother, who was a spy in the Spanish court, it was said; both could stay in the Court of Madrid. Finally, Marie-Catherine Aulnoy la Mothe 
died in Paris in 1705. She is one of the few authors whose work has been translated into Spanish and have various editions of several of her works ${ }^{13}$.

The work we have consulted and used in this paper is The Lady's travels into Spain; Genuine or relation of the Religion, Laws, Commerce, Customs, and Manners of That Country. Written by the Countess of Danois, in a series of letters to a friend at Paris. MDCCLXXIV (1774) (2 Vols.). This is a book where we are told the countess journey that she made from France to the court of Madrid, crossing the Pyrenees.

We are shown below several passages of the work of this author in which she described several geographical points of the peninsular north, as Vizcaya and Irun, while presents the character of the Basques, the characters of the Spanish women and Spanish wine:

"...This country called Biscay, is full of high mountains, where are several iron mines: the Biscayans climb up the rocks as easily, and

${ }^{13}$ Among many works: VV. AA.: "Marie-Catherine Le Jumel de Barneville, comtesse d'Aulnoy”, en Données encyclopédiques, Francia, 2001. www.fr.encyclopedia.yahoo.com/articles/a/a0006970_p0.html. (last visit 24/03/2016). VV.AA.: “d'Aulnoy, Comtesse (c. 1650- c. 1705)", en The Penguin Biiographical Dictionary of Women, 1998, www.xrefer.com/entry/172141 (last visit 24/03/2016). Aguilera, E. M.: “Notas prologales”, en Viaje por España en 1679 y 1680 y Cuentos feéricos, Barcelona, 1962, pp. XI y ss. Anónimo, Biographie de Marie-Catherine Le Julem de Barneville Baronne d’Aulnoy (1650-1705), www.contes.net/contes/aulnoy/bio_aul.html (last visit 20/03/2016). Anónimo, “Madame D’Aulnoy (D’aprés un article paru en 1870)”, en La France pittoresque, 1999-2002 www.france-pittoresque.com/perso/18.htm (last visit: 20/03/2016). Cardona Gamio, E.: “Madame D’Aulnoy”, en ¿Crees en las hadas?”, 2002 www.ccgediciones.com/Hadas/Biografias/biografias3.htm (last visit: 01/04/2016). García Mercadal, J.: Viajes de extranjeros por España y Portugal, Castilla y León, 1999, t. IV. Díez Borque, J. M.: La sociedad española y los viajeros del siglo XVII, Madrid, 1975, pp. 48 y ss. González de Amezúa, A.: Fantasías y realidades del viaje a Madrid de la Condesa d'Aulnoy, Madrid, pp. XX-XI. Guerrero, A. C.: Viajeros británicos en la España del siglo XVIII, Madrid, 1990, pp. 26 y ss. Sánchez Quevedo, M. I.: Un viaje por España en 1679, Madrid, 1995, pp. 48 y ss. VV. AA.: Memoirs of Women Writers, Vol. 5, p. 260. Macleud, G.: "Writer of Fantasy: Madame d'Aulnoy", en Women Writers of the Seventeenth Century, 1989, pp. 91-92. Guenther, M.: "L’Espagne sous le regard d'une Française: la Relation du voyage d'Espagne (1691) de Madame d'Aulnoy”, 452º : Revista de Teoría de la Literatura y Literatura Comparada, 2 (2010), pp. 127-136. Romero Alfaro, E.: "Reflexiones sobre la traducción de la 'Relation du voyage d'Espagne' de Madame d'Aulnoy”, en VII Coloquio APFUE, Cádiz, Vol. 1, 2000, pp. 447-458.

Marie-Catherine le Jumel de Barneville Aulnoy, G. Mercadal: Relación del viaje de España, Akal, 1986. Marie Catherine d'Aulnoy: Viaje por España en 1679, Círculo de Lectores, 2000. Madame d'Aulnoy: El cuarto de las hadas, Ediciones Siruela, Madrid. Marie Catherine d'Aulnoy: Mayúsculas y minúsculas 3 años. Libro guía del profesorado. Ediciones Akal. Marie Catherine d'Aulnoy: Mayúsculas y minúsculas 4 años. Libro guía del profesorado. Ediciones Akal. Marie-Catherine Le Jumel Barneville Aulnoy, Miguel Ángel Vega Cernuda, Rosa Pilar Blanco (trad.): Relación del viaje de España, Cátedra, Madrid, 2000.

See annex table $n^{\circ} 4$. 
with as great swifteness as stags: their language (if one may call such jargon language) is very poor, seeing one Word signifies abundance of things: there are none but those born in the country that can understand it; and I am told, that to the end it may be more particularly theirs, they make no use of it in writing; they oblige their children to read and write French and Spanish, according to which king's subjects they belong..." (Countess of d'Aulnoy, 1774, p. 11).

"Irun...this Little town is the first of Spain which you meet with, leaving France: it is ill built, the streets are unequal, and there is nothing one can speak of..." (Countess of d'Aulnoy, 1774, p. 12).

"These Young Biscaneers provoked, are worse than lions" (Countess of d'Aulnoy, 1774, p. 18).

"The Spanish women are more acressig than we, and are far more kind and tender to those they profess friendship" (Countess of d'Aulnoy, 1774, p. 143).

"...the excellent Spanish wine...comes from Andalusia and the Canary-Islands, which must pass the sea too, to gain that strength and pleasantness which we find in it. At Madrid the wine is strong enough, if not too strong, but it wants that delicious taste" (Countess of d'Aulnoy, 1774, p. 338).

\section{Stéphanie Félicité Genlis Bruslart, Madame Genlis (1746-1830)}

This women, together the following we will discuss, are the two authors most relevant in terms of literary production. Moreover, this is reflected in the multitude of literature on both there, unlike most of the rest of her colleagues discussed here ${ }^{14}$.

This is a French author, not only a writer but also an educator, who was born in Champéry on 25 January 1746, marrying at the age of sixteen with Brûlart Charles de Genlis (Genlis, 1794, pp. 51 and 79-81).

As an educator was very famous in her time and later, as she wrote numerous works using her theory of education, perhaps her most famous work in this regard is Théatre d'Éducation. It was an independent woman and became separated in 1782. She moved in the most select and French cultural circles of the time, and he met several times with Rousseau (Genlis, 1794, p. 95). In 1784, she had to take up residence in Berlin, and later in Hamburg, and it was there that Madame Genlis had to survive on her own literary and artistic production. Once past the French Revolution, and calm tempers, Madame Genlis returned to her native country in 1799.

14 This not only happens with the writers analyzed here, but the lack of biographical references extends to many other writers of whom we have little knowledge. For example, Fernández-Montesinos tells us about Mary Catherine Jackson, among others. (Hardy, 1982, pp. 74-75). 
The literary production of Stéphanie Félicité Genlis Bruslart not reduced to education, but also left her pen some historical novels. Its production reaches more than thirty works ${ }^{15}$. However, the work that we have taken as a reference because it is what makes mention of our country, is entitled A Selection from the Annals of Virtue, of Madame Sillery: Containing the Most Important and Interesting Anecdotes from the Histories of Spain, Portugal, China, Japan and America: With some account of the Manners, Customs, Arts and Sciences of France. Translated from the French by Elizabeth Mary James. M.DCC.XCIV (1794).

In this work, Madame Genlis does not describe a trip to Spain, but writes about the history of Spain. Therefore, her book is very different from the rest of the authors that we analyzed here. However, we decided to include it because it seemed interesting to compare with the rest of the traveling females. Madame Genlis tries to describe the Spanish monarchy since the Goths also describes the customs, laws and education in our country throughout history. For example, the Gothic kings she tells us that:

"The Gothic kings for a long time exercised an absolute power; but afterwards desirous to render themselves more beloved by their subjects and having learned from experience that a despotic authority is of all others the least durable, voluntarily limited their power, and acknowledged themselves subject to laws..." (Genlis, 1794, p. 81).

We can point to this case discrimination of women's stories in Spanish academic discourse, where if the stories of other foreign authors are studied in reference to our country, whereas, for example, this work of Madame Genlis is virtually unknown to the historians. We do not want to go deeper into the figure of this outstanding French author since the large literature on it has already seen the light can be viewed and analyzed in order to leave room in this paper to those most unknown authors.

\section{Mrs. Jemima Kindersley (1741-1809)}

Jemima was born in 1741 in Norwich and married in 1762 with Nathaniel Kindersley, this was an officer of the Company of the West Indies, so both had to travel from England to India in 1764, but before reaching their destination, they made a stop in the Canary Islands. She returned to England in 1769, however, her husband had to stay in India where he died a few months later.

Mrs. Jemima Kindersley was one of the first British women who published a work within the genre of travel literature. Her work was due to the experience that she lived on her trip to India seeing the light its

\footnotetext{
${ }^{15}$ See annex table $n^{\circ} 2$.
} 
publication in 1777. Nevertheless, our author not only wrote this work travel, but also published a book of essays translated from French philosopher, Antoine Leonard Thomas. Finally, our author and translator died in Bath in 1809.

The book that we have consulted Mrs. Kindersley entitled Letters from the East Indies. Letters from the Island of Teneriffe, Brazil, The Cape of Good Hope, and the East Indies. In it, the author makes a masterful geographical description and in relation to our country, on the island of Tenerife, its people, streets, neighborhoods, and perhaps it is the best geographic descriptive account, in our opinion, of all the authors analyzed here. This can be seen in the passages we mention below:

"...The Canary Islands, of which there are seven, are all subject to the king of Spain; this is the largest except one, which is called Grand Canaria..."

“...Santa Cruz consists of two or three streets, which are broad, but remarkably ill-paved; the houses are all white on the outside; those belonging to the pincipal people are large, and the different apartments, which are all upstairs, are built round a court or square, with a gallery on all sides leading to the rooms, which are mostly spacious, but are calculated more for coolness than for shew: The windows are not glazed but latticed, which give the houses, both on the in and outside, a mean appearance. But the lattices have these two conveniencies, they admit the air, and give the ladies an oppotunity of looking out without being seen...."

"...The number of inhabitants on the island are computed to be 96000. The governor and officers are appointed by the king of Spain; the inhabitants are all Spanish subjects, and the Europeans call themselves Spaniards..."18.

“...Laguna, usually called the city: which is a pretty large town, and regularly built, but quite unornamented, and silent as the night. Many of the principal people at Santa Cruz have houses there, which they go to by way or retirement from business. Laguna is about five miles from the sea..."19.

As pointed above, Mrs. Jemima Kindersley is the author that best describes the geography of the areas through which it passes. As for our country, she describes perfectly the Canary Islands, not only makes a

\footnotetext{
${ }^{16}$ Mrs. Jemima Kindersley: Letters from the East Indies. Letters from the Island of Teneriffe, Brazil, The Cape of Good Hope, and the East Indies, London: Saunders and Otley, Conduit Street, 1843, p.

${ }^{17} \mathrm{P}$. Traducción realizada por la autora del presente trabajo.

${ }^{18} \mathrm{P}$. Traducción realizada por la autora del presente trabajo.

${ }^{19} \mathrm{P}$. Traducción realizada por la autora del presente trabajo.
} 
description of number of inhabitants, but also makes a magnificent urban description of towns and cities. In her account, a certain evolution is compared to previous authors, because, perhaps, preconceived ideas are not so evident in this period.

\section{Henrietta Maria Georgiana Chatterton, Lady Chatteron (1806-1876)}

Lady Chatterton was a British traveler and a prolific author who wrote more than thirty books ${ }^{20}$. She born in London in the early nineteenth century -1806-, and in 1824 married Sir William Abraham Chatterton. This is not only an author of travel; in fact, her fame comes thanks to their stories, novels and histories. She was widowed in 1855 and remarried four years later with Mr. Edward Dering Henage. Finally, she died in Malvern in $1876^{21}$.

The work that we have analyzed is the literature pertaining to travel; work composed in two volumes entitled The Pyrenees into Spain With Excursions. In it, Lady Chatterton, describes his travels through the Pyrenees, making a magnificent geographical description of the places through which it passes. In several passages of her work can be seen descriptions inserted into her account of the houses, food, nature of Spanish, music, neighborhood, etc., but one of the issues that most we are interested in is the description made on the Spanish women:

"The decorations of the houses and beautiful carving of the projecting balconies announce a splendour which no longer exists..." (Lady Chatterton, 1843, p. 194).

"The Spanish bread is so much better than the French..." (Lady Chatterton, 1843, p. 213).

"... here were other ladies assembled, and more refreshments, and afterwards we had some good music. Two gentlemen sang some beautiful Spanish airs to a guitar accompaniment, and then some ladies alternately took the instrument, and delighted us by the graceful and plaintive manner in which they sang. I understood that the greatest equality exists in society. Every person in the town, high and low, is known to his neighbour, and rich and poor are on a certain footing of intimacy...” (Lady Chatterton, 1843, pp. 208-209)..

\footnotetext{
${ }^{20}$ See annex table $n^{0} 3$.

21 “Chatterton, Henrietta Georgiana Marcia Lascelles”. Dictionary of National Biography. London: Smith, Elder \& Co. 1885-1900. Catalogue 200 (London: Jarndyce Antiquarian Booksellers, 2012. Literary Heritage: Georgiana Chatterton profile (http://www3.shropshirecc.gov.uk./people/chattert.htm) (last visit 20/04/2016). In spite of the prolific of its literary trajectory, the fact is that the biographical works that have been realized on this author in the international panorama still exist, and less it fits in the Spanish.
} 
"...but I belive that the women in this country soon look old, for I remarked that we seldom see anything but young girls and old women. It was a very pinturesque spectacle; the whole party were dancing "rondes" in great glee, and the bright-red peticoats of the women, with the white cap and blue boddice, looked very vivid and pretty..." (Lady Chatterton, 1843, p. 102).

"...The influence that women have often exercised over the destinies of nations, induces some persons to imagine that their mental powers are naturally not inferior to those of men. I think, however, this influence arises, not from the superiority, but on the contrary, from the inferiority of their intellect. To be influenced is rather a sign of a superior intellect that can afford to bow down, and give way to the weaker sex. Obstinate, and narrow, or weakminded men, are rarely influenced -they are, indeed, often compelled and driven- by a clever wife or mistress, but this is quite different from being influenced..." (Lady Chatterton, 1843, pp. 111-112).

"...It consisted almost entirely of women, dressed in black, with their mantillas; they were grouped in lines of five or six, and knelt upright, with small tapers burning on the floor before them; their immovable figures, apparently absorbed in devotion, gave a peculiar solemnity to the scene..." (Lady Chatterton, 1843, p. 195).

"...Women are no longer permitted to become nuns in Spain, and all the monasteries have been done away with...the ladies were all in the aisle, and the universal mantilla, worn over..." (Lady Chatterton, 1843, p. 205).

"...the ladies still wearing their mantillas, and the peasantry attired in their holiday costume, but contrary to the usual habits of other nations, the dress of the men was far more brilliant and varied than that of the women..."(Lady Chatterton, 1843, p. 210).

"...Some of the women of the lower orders, had, indeed, peticoats of a bright-red, or yellow cloth; the black mantillas, however, invariably covered the neck and shoulders -and the most common colour amongst the older women black..." (Lady Chatterton, 1843, p. 211).

Lady Chatterton protrudes from the description that she makes of the females Spanish; also, it shows both a description of the women of high society as those of a lower social class. In addition, this author is puzzled by the customs and Spanish traditions, such as music and religious rituals of many of the acts of the Spanish society. Thus, it is shown truly surprised by the blanket and both male and female clothing used by the different social strata for the celebrations, very different from that used in her country of origin. 


\section{Sophia Barnard (XIXth century)}

Sophia Barnard married a merchant and visited Cadiz when this was being bombed by the French in 1811, under the context of the War of Spanish Independence (1810-1814). It was an adventurous woman who composed her work through a compendium of her trips she made between 1811 and 1814. It is one of the most unknown traveling-writers discuss here $^{22}$. Therefore, we do not know many details of her life and work, which try to remedy in future studies.

The work we have used has been Travels in Algeirs, Spain, \& c. \& C. with a faithful and interesting account of the Algerines, amongst Whom the Authoress resided some time, and from her Access To Whom, She Had many Opportunities of discovering and apreciating Their customs, ceremonies, pursuits, costume, \& $c$. Which no historian has before detailed with a minuteness due to extraordinary and interesting That race of people: Also a copious description of her residence in Andalusia, abounding in remarkable events, anecdotes of persons, places, product, \& c. (C. 1820). Here Sophia Barnard tells her trip to Cadiz where the war took place perfectly describes the situation of the people and the cruelty of the armed conflict. In the passages below can be appreciated her interest in the urban city and impressions that the provincial capital and their wives came to her:

"...The churches were good but gaudily decorated, and I thought surely pomp and ostentation ever will stare modesty and piety out of countenance. I saw some priests and confessors whose dresses were black and White cloths, with large loose sleeves, cloth hats to match their dresses, with crowns to fit the head; the brims immensely large, turned up before and behind, and wrapped over the Crown..." (Barnard, 1820?, p. 19).

“...Cadiz is the central mart for Spanish American commerce. House rent and provisions were far from cheap. I was astonished to hear, that though this climate and soil were admirable... The pastures, vineyards, fruit, vegetables and wine were excellent..." (Barnard, 1820?, p. 21).

"The women are handsome, their eyes are dark and fine" (Barnard, 1820?, p. 19).

Sophia Barnard also is surprised by what she finds on its way through the provincial capital. It is surprised, among other things, by the ostentation with which the churches are decorated, especially considering that a vision of Spain of backward country compared to others be had, so the surprise was

\footnotetext{
${ }^{22}$ We have only been able to locate an article that refers to this writer: Gifra-Adroher, P.: "Witness to the Peninsular War: Sophia Barnard's travels in Andalusia", Cuadernos de Ilustración y Romanticismo, Revista Digital del Grupo de Estudios del Siglo XVIII, 18 (2012), pp. 155-175.
} 
greater. Similarly, she was surprised, like many of her colleagues, the whole ritual that has to do with religious acts, including clothing of priests and confessors as can be seen in one of the above passages. However, Sophia Barnard describes not only the religious sumptuousness of Spain, but also shows interest and admired by the great mall that was Cadiz, the hub of commercial transactions with the American continent. Therefore, we can see a conjunction in her descriptions between the important and the tangential. The first would refer to as mall Cadiz, the life of the city, the excellence of its cuisine and at the same time so expensive that all was a result of armed conflict suffered by the city. While the second, tangential, would be that glitz and pomp of religion, among other things.

\section{Conclusion}

If we analyze all these works, we can see an evolution in the way of describing Spain, from the seventeenth century to the first half of the nineteenth century.

All authors describe the manners and customs of the Spaniards in their stories. At the same time, all emphasize the passions and love, the beauty of women, in archaic Spanish customs, but we must not lose sight that make it from the perspective of the Other, in this case, of the others, French and British, whose nations were more powerful, were more developed and more "civilized" than the Spanish. Therefore, their customs were more refined than those found in a country that had not modernized, even though the influence of the French style. Hence, Sophia Barnard felt fascinated by mantillas for women and lavishness of men dressing as opposed to simplicity of the female attire in her native country.

These females describe very well the vicissitudes of their travels, the difficulties of access to Spain, either by sea or land, although generally produced through the Pyrenees.

They describe in their different works clothes, buildings, food, roads, customs, and especially the lives of Spanish females, that is to practically an overview of the uses and customs that were in our country.

Descriptions obviously conform to the reality of the moment lived, that is, depending on the time in which it is inserted, and responds to the situation of Spain itself. Therefore, prejudice incurred before stepping on Spanish territory are visible in the descriptions that these females made not only of the Spanish geography, but above all, customs and life of Spanish, as is for example the description of the Basques made by the Countess d'Aulnoy. Moreover, being women is normal they paid attention to life, relationships and customs that Spanish females had. Hence, the vision of these traveling-writers is so important for not only travel literature, but also, for historiography, as it enables to complete the vision and the idea that 
traveling-writers have throughout history of Spain, they describe it from another perspective and another point of view.

Therefore, we must not ignore, not only in travel literature, but also in any plot of historical knowledge, what women have to say or / and write. If we take an overview of what all travelers, whether men or women, make of Spain, we can get an idea of the vision of our country, both geographically and in terms of their customs, in the view of the Other.

The traveling-writers, especially women, usually conceive the scriptural act more like a hobby than a way of life; however, there are also exceptions, such as Madame d'Aulnoy. Thus, some authors suggest that their work concerning Spain has many overtones of fiction; hence, some authors believe that Madame d'Aulnoy was never in our country.

The eighteenth century was the awareness of the significance of the trip, the rise of literature at European level, where Spain was the epicenter of countless journeys of countless travelers across Europe (Bas Martín, 2011, pp. 129-143). We have seen how the nineteenth century (Freire López, pp. 67-82) was the neater; perhaps, in terms of travel literature is concerned, and more particularly it that produced by women (Ferrús Antón, pp. 1-10). Not only there were more travelers who were attracted to Spain, but the nineteenth century was also the century that saw many Spanish travelers outside our borders (Peñate Rivero, pp. 245-268).

On the other hand, the topics (Ortega Román, pp. 207-232) that are seen in travel literature produced by the male are similar to those detected for these women. We find phrases that are practically equivalent from the descriptions of the seventeenth century to the nineteenth century, where ideas preconceived by these women before stepping our country, which, however, when they come here do not change substantially, but rather the perception obtained conforms to the preconceived perception.

We have found that, whatever the sex of the producer of this type of literature, it is a basic documentary source to better understand each of the moments described; also are a source of great documentary importance to appreciate the urban and geographical development of all the places described (Chaves Martín, 2012, pp. 57-83; Bas Martín, 2007, pp. 9-16). Therefore, this paper tries to approach these women writers in a first attempt to make them known, we especially refer to Sophia Barnard, Lady Chatterton, Mrs. Jemima Kindersley and Ann Lady Fanshawe, and in future works will try to focus them to go deeply into, perhaps individually, the analysis of their works.

\section{References:}

1. Aguilera, E. M. (1962). “Notas prologales”, Viaje por España en 1679 y 1680 y Cuentos feéricos, Barcelona. 
2. Alburquerque García, L. (2014). “Literatura de viajes y siglo XVIII español: repaso y sistematización”, Miríada hispánica, 9, pp. 37-51.

3. Almarcegui, P. (2011). "El Otro y su desplazamiento en la última literatura de viaje”, Revista de Literatura, vol. LXXIII, 145, pp. 283290.

4. Anonymous, Biographie de Marie-Catherine Le Julem de Barneville Baronne d'Aulnoy

(1650-1705), www.contes.net/contes/aulnoy/bio_aul.html

5. Anonymous, “Madame D’Aulnoy (D’aprés un article paru en 1870)”, La France pittoresque, 1999-2002 www.francepittoresque.com/perso/18.htm

6. Arranz Lago, D. F. (2014). “La literatura de viajes en el tiempo: orígenes e hitos”, Crítica, 990, pp. 76-79.

7. Barnard, S. (1820?). Travels in Algeris, Spain, \&c. \&c. With a faithful and interesting account of the Algerines...London: Goyder, 415, Strand also by Barry and son, Booksellers, Bristo.

8. Bas Martín, N. (2007). "Los repertorios de libros de viajes como fuente documental”, Anales de documentación: Revista de biblioteconomía y documentación, 10, pp. 9-16.

9. Bas Martín, N. (2011). "El viaje como formación: ejemplos de la literatura europea del siglo XVIII”, Historia de la educación: Revista interuniversitaria, 30, pp. 129-143.

10. Basnnett, M.: “All the ceremonyes and civilityes: The Autorship of Diplomacy in the Memoirs of Ann, Lady Fanshawe", en http://www.tandfonline.com/doi/pdf/10.1080/0268117X.2011.10555 660

11. Campa Carmona, R. de la (2003). "Iglesia y religiosidad española según la condesa d’Aulnoy (Segunda mitad del siglo XVII), Coloquio internacional Los Extranjeros en la España Moderna, Málaga, T. II, pp. 161-174.

12. Cardona Gamio, E. (2002). “Madame D’Aulnoy”, en ¿Crees en las hadas?”, www.ccgediciones.com/Hadas/Biografias/biografias3.htm

13. Chaves Martín, M. A. (2012). "El viaje y sus relatos. Una aproximación a la construcción de la imagen de la ciudad histórica”, Icono14, Vol. 10, 2, pp. 57-83.

14. Davison, P. (2004). “Fanshawe, Ann, Lady Fanshawe (1625-1680)”, Oxford Dictionary of National Biography, Oxford University Press.

15. Díez Borque, J. M. (1975). La sociedad española y los viajeros del siglo XVII, Madrid.

16. Fernández-Montesinos, A.E. (2004). "Viajeras inglesas y norteamericanas en Andalucía: visiones alternativas en textos 
inéditos en su traducción”, in Arriaga Flórez, M. (coord.), Mujeres, espacio y poder, pp. 224-232.

17. Fernández-Montesinos, A. E. (2008), Viajeras románticas en Andalucía. Antología, Sevilla, Centro de estudios andaluces. Consejería de la Presidencia.

18. Ferrús Antón, B. (2011). “Emilia Serrano, baronesa de Wilson, y la literature de viajes: "Maravillas americanas" y "América y sus mujeres”, Cuadernos de Ilustración y Romanticismo: Revista Digital del Grupo de Estudios del siglo XVIII, 17, pp. 1-10.

19. Freire López, A.M. (2012). "España y la literatura de viajes en el siglo XIX”, Anales de literatura española, 24, pp. 67-82.

20. García Mercadal, J. (1999). Viajes extranjeros por España y Portugal desde los tiempos más remotos hasta comienzos del siglo $\mathrm{XX}$, Valladolid, Junta de Castilla y León, 6 vols.

21. García-Romeral Pérez, C. (1999). Bio-bibliografía de viajeros por España y Portugal (siglo XIX), Madrid, Ollero y Ramos.

22. Gijón Jiménez, V. (2014). "La docencia de la historia a través de la literatura de viajes”, in Díaz-Cuesta Gallán, J. y Gaona Pisonero, C. (coords.): Creatividad e innovación en el espacio europeo, pp. 339354.

23. Gómez Espelosín, F. J. (2006). "Viajes de verdad, viajes de mentira: literatura de viajes del período helenístico”, Revista de Filología Románica, anejo IV, pp. 59-75.

24. González de Amezúa, A.: Fantasías y realidades del viaje a Madrid de la Condesa d'Aulnoy, Madrid.

25. Guenther, M. (2010a). "España bajo la mirada de una francesa: $L a$ relación del viaje de España (1691) de Madame d’Aulnoy”, Revista electrónica de teoría de la literatura y literatura comparada, 2, pp. 127-136.

26. Guenther, M. (2010b). “L’Espagne sous le regard d'une Française: la Relation du voyage d'Espagne (1691) de Madame d'Aulnoy”, 452 ${ }^{\circ} \mathrm{F}$ : Revista de Teoría de la Literatura y Literatura Comparada, 2, pp. 127-136.

27. Hardy, J. C. (1982). A catalogue of English prose fiction mainly of the eighteenth century from a private library.

28. Gifra-Adroher, P. (2012). "Witness to the Peninsular War: Sophia Barnard's travels in Andalusia”, Cuadernos de Ilustración y Romanticismo, Revista Digital del Grupo de Estudios del Siglo XVIII, 18, pp. 155-175.

29. Guerrero, A. C. (1990): Viajeros británicos en la España del siglo XVIII, Madrid. 
30. Harlin Mcburney, W. (1960). A check list of English prose fiction. 1700-1739, Harvard University press. Cambridge, Massachussetts.

31. Henrietta Georgiana Maria Chatterton, Lady Chatteron (1843). The Pyrenees with excursions into Spain. London: Saunders and Otley, Conduit Street.

32. Henríquez Jiménez, S. J. (2012). “La lectura de la literatura de viajes: nuevos textos, líneas de investigación, elementos y fundamentos teóricos”, in Marrero Henríquez, J. M. (coord.), La luz no interrumpida, pp. 293-304.

33. Mrs. Jemima Kindersley (1843). Letters from the East Indies. Letters from the Island of Teneriffe, Brazil, The Cape of Good Hope, and the East Indies, London: Saunders and Otley, Conduit Street.

34. Krauel Heredia, B. (1986). Viajeros británicos en Andalucía de Christopher Hervey a Richard Ford (1760-1845), Málaga, Publicaciones de la Universidad.

35. Loftis, J. (1979). The Memoirs of Anne, Lady Halkett and Ann, Lady Fanshawe, Oxford: Clarendon Press.

36. Macleud, G. (1989). "Writer of Fantasy: Madame d'Aulnoy”, en Women Writers of the Seventeenth Century.

37. Madame Genlis (2010). La escritora. Una mujer del siglo de las luces y su conflicto entre el amor y la voluntad de escribir, Erasmus Ediciones, Barcelona.

38. Majada Neila, J. (2001). 500 libros de viaje sobre Málaga, Benalmádena, Caligrama ediciones.

39. Marcillas Piquer, I. (2012). "Literatura de viajes en clave femenina: los pre-textos de Aurora Bertrana y otras viajeras europeas”, Revista de filología románica, 29-2, pp. 215-231.

40. Marchant Rivera, A. (2008). “Escritura femenina y viajera: visiones de Lady E. Mary Grosvenor, Louise M. A. Tenison, M. C. Jackson y Olive Patch sobre el cementerio inglés de Málaga”, in Gómez Yebra, A., Estudios sobre el patrimonio andaluz, AEDILE, pp. 141-158.

41. Marchant Rivera, A. (2011). "Escritura femenina y viajera II: Dora Quillinam, Margaret Thomas y Valéire de Gasparin en el Cementerio Inglés de Málaga”, in Gómez Yebra, a. (coord.), Patrimonio literario andaluz (IV), pp. 69-84.

42. Marchant Rivera, A. (2013). “El cementerio inglés de Málaga y sus fuentes historiográficas: los libros de viaje femeninos del siglo XIX”, in Marchant Rivera A. y Rodríguez Marín, F. (coords.), La muerte desde la arqueología, la historia y el arte, pp. 75-92.

43. Marchant Rivera, A. and Muñoz Jiménez, A. B. (2012). “Escritura francófila y anónima Matilda Betham Edwards y Caroline $\mathrm{H}$. Pemberton en el cementerio inglés de Málaga (1867)”, in Gómez 
Yebra, A. (coord.): Estudios sobre el patrimonio literario andaluz IV, pp. 81-96.

44. Marie-Catherine le Jumel de Barneville Aulnoy, G. Mercadal (2000). Relación del viaje de España, Akal, 1986. Marie Catherine d’Aulnoy: Viaje por España en 1679, Círculo de Lectores.

45. Madame d'Aulnoy. El cuarto de las hadas, Ediciones Siruela, Madrid. Marie Catherine d'Aulnoy: Mayúsculas y minúsculas 3 años. Libro guía del profesorado. Ediciones Akal. Marie Catherine d’Aulnoy. Mayúsculas y minúsculas 4 años. Libro guía del profesorado. Ediciones Akal.

46. Marie-Catherine Le Jumel Barneville Aulnoy, Miguel Ángel Vega Cernuda, Rosa Pilar Blanco (trad.) (2000). Relación del viaje de España, Cátedra, Madrid.

47. Martínez Alonso, P. J. (2003). Libros de viajes alemanes e ingleses a España en el siglo $X X$, Tesis doctoral, Universidad Complutense de Madrid.

48. Mékouar-Hertzberg, N. (2014). "Construcciones de las subjetividades femeninas en la literatura. El viaje de Penélope”, in Chocarro de Luis, E. y Sáenz Berceo, M. C. (eds.): Oriente y occidente: la construcción de la subjetividad femenina, Logroño, Universidad de la Rioja.

49. Middleton, D. (1982). Victorian Lady Travellers, Chicago, Academy.

50. Mitchell, D. (1989). Viajeros por España. De Borrow a Hemingway, Madrid, Mondadori.

51. Montoro Fernández, F. (2014). "Mujeres viajeras y Vélez-Málaga”, Sociedad: boletín de la Sociedad de Amigos de la Cultura de VélezMálaga, 13, pp. 43-48.

52. Ortega Román, J. J. (2006). "La descripción en el relato de viajes: los tópicos”, Revista de filología románica, Extra 4, pp. 207-232.

53. Ozlem, E. (2004). "A challenge to travel Literature and stereotypes by two turkish women: Zeyneb Hanoum and Selma Ekrem", Feminismo/s, 4, pp. 61-67.

54. Pamer, M. D. (1975). "Madame d'Aulnoy in England”, Comparative Literature, Vol. 27, 3, pp. 237-253.

55. Peñate Rivero, J. (2011). "Viajeros españoles por Europa en los años cuarenta del siglo XIX: tres formas de entender el relato de viaje", Revista de literatura, T. 73, 145, pp. 245-268.

56. Romero Alfaro, E. (2000). "Reflexiones sobre la traducción de la 'Relation du voyage d'Espagne' de Madame d'Aulnoy", en VII Coloquio APFUE, Cádiz, Vol. 1, pp. 447-458.

57. Romero Tobar, L. (2011). "Imágenes poéticas en textos de viajes románticos al Sur de España”, Revista de literatura, T. 73, 145, pp. 233-244. 
58. Salido López, P.V. (2011). “La literatura de viajes como fuente para la investigación”, en Collado Yurrita, M. A. y Hernández Adrover, J. J. (coords.), I Jornadas Doctorales de Castilla-La Mancha: El doctorado: impacto social y futuro profesional, Ciudad Real, p. 70.

59. Sánchez Quevedo, M. I. (1995). Un viaje por España en 1679, Madrid.

60. Serrano, M. M. (1993). Viajes de papel: repertorio bibliográfico de guías y libros de viaje por España 1800-1902, Barcelona, Publicaciones de la Universidad de Barcelona.

61. Simón Alegre, A. I. and Sanz Álvarez, A. (2010). "Prácticas y teorías de descubrir paisajes: viajeras y cultivadoras del estudio de la geografía en España, desde finales del siglo XIX hasta el primer tercio del XX”, Arenal: Revista de historia de las mujeres, Vol. 17, 1, pp. 55-79.

62. Stéphanie Félicité Bruslart Genlis (1794). A Selection from the Annals of Virtue, of Madame Sillery: Containing the Most Important and Interesting Anecdotes from the Histories of Spain, Portugal, China, Japan and America: With some account of the Manners, Customs, Arts and Sciences of France. Translated from the French by Elizabeth Mary James. M.DCC.XCIV.

63. Suárez Suárez, C. (2013a). “Viajeras y aventureras (I)”, in Cid López, R. M. (coord.), Horas de radio: sobre mujeres e historia, pp. 82-86.

64. Suárez Suárez, C. (2013b). "Viajeras y aventureras (II)”, in Cid López, R. M. (coord.), Horas de radio: sobre mujeres e historia, pp. 87-90.

65. Tamarit Vallés, I. (2004). Representaciones de la mujer española en el imaginario francés del siglo XVIII, Tesis doctoral, Universidad de Valencia.

66. Torralbo Caballero, J. D. (2010). "Mujer y escritura en la Inglaterra de los siglos XVII y XVIII: Corte, autobiografía y reivindicación”, Anglogermanica Online, pp. 85-99.

67. Triquet, C. (2007). “On the Literary Origins of Folkloric Fairy Tales: A Comparison between Madame d'Aulnoy’s “Finette Cendron” and Frank Bourisaw’s “Belle Finette”, Marvels \& Tales, Vol. 21, 1, pp. 34-49.

68. VV.AA. (1998). “d’Aulnoy, Comtesse (c. 1650- c. 1705)”, en The Penguin Biiographical Dictionary of Women, retrieved from www.xrefer.com/entry/172141

69. VV. AA. (2001). "Marie-Catherine Le Jumel de Barneville, comtesse d'Aulnoy”, en Données encyclopédiques, Francia, retrieved from: www.fr.encyclopedia.yahoo.com/articles/a/a0006970_p0.html. 
70. VV. AA.: Memoirs of Women Writers, Vol. 5.

Annexes

Table $\mathbf{n}^{0}$ 1: Works consulted from the six women writers analyzed

\begin{tabular}{|c|c|}
\hline AUTHOR & WORK CONSULTED \\
\hline Ann Lady Fanshawe & $\begin{array}{l}\text { Memoirs of Lady Anne Fanshawe, wife of Sir Richard Fanshawe, Bart. } \\
\text { Written by herself. }\end{array}$ \\
\hline $\begin{array}{l}\text { Marie-Catherine La } \\
\text { Mothe Aulnoy }\end{array}$ & $\begin{array}{l}\text { The lady's travels into Spain; or, a genuine relation of the religion, laws, } \\
\text { commerce, customs, and manners of that country. London: Printed for T. } \\
\text { Davies, in Russel-Streets, Covent-Garden, } 1774 \text {. }\end{array}$ \\
\hline $\begin{array}{l}\text { Stéphanie Félicité } \\
\text { Bruslart Genlis }\end{array}$ & $\begin{array}{c}\text { A selection fron the Annals of Virtue, of Madame Sillery: containing the } \\
\text { most important and interesting anecdotes from the Histories of Spain, } \\
\text { Portugal, China, Japan and America: with some account of the manners, } \\
\text { customs, arts and sciences of France. Translated from the French by } \\
\text { Elizabeth Mary James ( } 1^{\text {st }} \text { ed.). Bath: Printed by S. Hazard, for the } \\
\text { author; and sold by Hookham and Co., New-Bond-Street, Richardson, } \\
\text { Royal-Exchange, London; S. Hazard, of Bath and by all other } \\
\text { Booksellers, } 1794 .\end{array}$ \\
\hline Mrs. Jemima Kindersley & $\begin{array}{l}\text { Letters from the Island of Teneriffe, Brazil, the Cape of Good Hope, and } \\
\text { the East Indies. London: printed for J. Nourse, in the Strand, Bookseller } \\
\text { to his Majesty, } 1777 .\end{array}$ \\
\hline $\begin{array}{l}\text { Henrietta Georgiana } \\
\text { Maria Chatterton }\end{array}$ & $\begin{array}{l}\text { The Pyrenees with excursions into Spain. London: Saunders and Otley, } \\
\text { Conduit Street, } 1843 .\end{array}$ \\
\hline Sophia Barnard & $\begin{array}{c}\text { Travels in Algeris, Spain, \&c. \&c. With a faithful and interesting account } \\
\text { of the Algerines...London: Goyder, 415, Strand also by Barry and son, } \\
\text { Booksellers, Bristo, 1820? }\end{array}$ \\
\hline
\end{tabular}

Table $\mathrm{n}^{0}$ 2. Literary output of Stéphanie Félicité Bruslart Genlis.

\begin{tabular}{|c|c|}
\hline Work & Year of publication \\
\hline Le Siège de la Rochelle, ou, le Malheur et la Conscience & 1807 \\
\hline Les voeux téméraires; eu, L’enthousiasme & 1799 \\
\hline Théâtre à l'usage des jeunes personnes & 1783 \\
\hline $\begin{array}{l}\text { Mémoirs wédits de Madame la contesse de Genlis: pour servir à l'histoire des } \\
\text { dix-... }\end{array}$ & 1825 \\
\hline Tales of the castle & 1793 \\
\hline \multicolumn{2}{|l|}{ Ines de Castro } \\
\hline \multicolumn{2}{|l|}{ Adèle et Théodore, ou leters sur l'éducation } \\
\hline $\begin{array}{c}\text { Les chevaliers du cygne, ou la cour de Charlemagne: conte historique et moral } \\
\text { pour servir de... }\end{array}$ & 1795 \\
\hline Petrarch & 1820 \\
\hline Arabesques mythologiques, ou les atiributs de toutes les divinités de la fa ble... & 1810 \\
\hline Suite des souvenirs de Félicite & 1823 \\
\hline $\begin{array}{l}\text { The knights of the swan: or, the court of Charlemagne, a historical and moral } \\
\text { tale }\end{array}$ & 1797 \\
\hline Discours moraux sur divers sujets, et particulièrement sur l'éducation & 1802 \\
\hline $\begin{array}{l}\text { Histoire de Henri le Grand } \\
\end{array}$ & 1815 \\
\hline Les monuments religieux, ou, description critique et détaillée des monuments & 1805 \\
\hline $\begin{array}{l}\text { Zuma, ou, la Découverte sou quinqina: suivi de la belle paule, de Zenéide, des } \\
\text { Roseaux du tibre }\end{array}$ & 1817 \\
\hline Lessons of a gourness to her pupils. & 1808 \\
\hline Bélisaire & 1808 \\
\hline Les parvenus, ou les aventures de sulien delmours: écrites par lui-même & 1824 \\
\hline Contes Moraux & 1785 \\
\hline
\end{tabular}




\begin{tabular}{|c|c|}
\hline The theatre of education & 1819 \\
\hline Les meres rivales & 1800 \\
\hline The history of the duchess of C--, from Adela and Theodore & 1804 \\
\hline La duchesse de la Vallière & 1804 \\
\hline The history of the Dutchess of C-- & 1803 \\
\hline Mademoiselle de Clermont & 1818 \\
\hline Les petits émigrés & 1812 \\
\hline Théatre de Société & 1781 \\
\hline Théâtre à l'usage des jeumes personnes & 1779 \\
\hline Sacred dramas & 1797 \\
\hline Siège de la Rochelle & 1813 \\
\hline The child of nature & 1806 \\
\hline Les annales de la vertu & 1811 \\
\hline The beauties of Genlis & 1787 \\
\hline Les vetllées du château & 1842 \\
\hline $\begin{array}{l}\text { Souvernirs de Félicite } \\
\end{array}$ & 1857 \\
\hline $\begin{array}{l}\text { De l'influence des femmes sur la littérature françase, comme protectrices de } \\
\text { letters et comme auteurs }\end{array}$ & 1811 \\
\hline Bélisaire & 1810 \\
\hline Mademoiselle de la Fayatte & 1813 \\
\hline Religion considered as the only basis of hapiness and the true philosophy & 1787 \\
\hline Madame de Maintenon & 1825 \\
\hline La botanique historique et litteraire & 1810 \\
\hline Les oîners du Baron d’Holbach & 1822 \\
\hline Les battuécas & 1817 \\
\hline Les soupers de la meréchale de Luxembourg & 1828 \\
\hline Herbier moral & 1801 \\
\hline Placide & 1817 \\
\hline
\end{tabular}

Table $n^{\circ}$ 3. Literary output of Lady Chatterton

\begin{tabular}{|c|c|}
\hline Work & Year of publication \\
\hline The lost bride & 1872 \\
\hline Compensation: a story of real life thirty years ago & 1856 \\
\hline Memorials personal and historical of admiral Lord Gambier, G.C.B. & 1861 \\
\hline A good match: the heiress of drosberg, and the catedral choraster... & 1840 \\
\hline $\begin{array}{c}\text { Memoirs of Georgiana, Lady Chatterton: with some passages from her } \\
\text { dairy. }\end{array}$ & 1878 \\
\hline Oswald of Deira: a drama & 1867 \\
\hline The heiress and her louers: a novel & 1863 \\
\hline Aunt Dorothys tale, or, Geraldine Morton: a novel & 1837 \\
\hline The reigning beauty & 1858 \\
\hline The Pyreness: with excursions into Spain & 1843 \\
\hline Home Sketches and foreign recolletions & 1841 \\
\hline Leonore, a tale, and other poems & 1864 \\
\hline Rambles in the south of Ireland during the year 1838 & 1839 \\
\hline Life and its realities & 1857 \\
\hline Lady May: a pastoral & 1869 \\
\hline Country Coteries & 1868 \\
\hline Allanston; or, The infidel: a novel & 1844 \\
\hline Aunt Dorothy's tale, or, Geraldine Morton: a novel & 1837 \\
\hline Compensation: a story of real life thirty years ago & 1856 \\
\hline Country coeries & 1868 \\
\hline A good match, The heiress of Drosberg, and The catedral chorister... & 1840 \\
\hline
\end{tabular}




\begin{tabular}{|c|c|}
\hline Grey's Court & 1865 \\
\hline The heiress and her lovers: a novel & 1863 \\
\hline Home sketches and foreign recollections & 1841 \\
\hline Lady May, a pastoral & 1869 \\
\hline Lenore, a tale: and other poems & 1864 \\
\hline Life and its realities & 1857 \\
\hline The lost bride & 1872 \\
\hline Lost happiness; or, The effects of a lie & 1845 \\
\hline Memoirs of Georgiana, Lady Chatterton, with some passages from her diary & 1901 \\
\hline Memoirs of Georgiana, Lady Chatterton. With some passages from her diary & 1878 \\
\hline Memorials personal and historical of Admiral Lord Gambier & 1861 \\
\hline Oswald of Deira: a drama & 1867 \\
\hline The Pyreness, with excursions into Spain, by Lady Chatterton & 1843 \\
\hline Rambles in the south of Ireland during the year 1838 & 1839 \\
\hline Rambles in the south of Ireland during the year 1838, by Lady Chatterton... & 1839 \\
\hline The reigning beauty & 1858 \\
\hline Selections from the Works of Plato & 1862 \\
\hline
\end{tabular}

Table $n^{\circ}$ 4. Literary output Madame d’Aulnoy

\begin{tabular}{|c|c|}
\hline Work & $\begin{array}{c}\text { Year of } \\
\text { publication }\end{array}$ \\
\hline The history of the tales of the fairies & 1800 ? \\
\hline $\begin{array}{c}\text { Queen Mab: containing a select collection of only the best, most instructive, and } \\
\text { entertaining tales of the fairies }\end{array}$ & 1799 \\
\hline $\begin{array}{c}\text { The fairies: or surprising and entertaining adventures of the aerial beings;...the } \\
\text { whole to amuse and improve juvenile minds }\end{array}$ & 1795 \\
\hline Mother bunch's fairy tales & 1795 \\
\hline The history of the tales of the fairies: Newly done from the French & 1785 ? \\
\hline Histoire D’Hypolite: Comte de Duglas & 1782 \\
\hline $\begin{array}{c}\text { Memoirs of the Countess D’Anois: written by herself before her retirement. In } \\
\text { two volumes }\end{array}$ & 1778 \\
\hline $\begin{array}{c}\text { The earl of Douglas: an English story. From the French of the Countess D'Anois. } \\
\text { In three volumes }\end{array}$ & 1774 \\
\hline $\begin{array}{c}\text { The lady's travels into Spain: or, a genuine relation of the religion, laws, } \\
\text { commerce, customs, and manners of that country. }\end{array}$ & 1774 \\
\hline A collection of novels and tales of the fairies. & 1766 \\
\hline The history of John of Bourbon, Prince of Carency & 1724 \\
\hline The prince of Carency: a novel. & 1719 \\
\hline Memoirs of the Court of England: in the reign of King Charles II & 1708 \\
\hline The secret history of Mack-Beth: King of Scotland & 1708 \\
\hline Memoirs of the court of France, and city of Paris & 1702 \\
\hline
\end{tabular}

